\title{
GAM MODEL AND TOURIST VALORIZATION OF GEOSITES PLOČNIK
}

\author{
MIROSLAV STANKOVIĆ ${ }^{1}$, STEFAN MILOVANOVIĆ ${ }^{*}$ \\ ${ }^{1}$ Faculty of Natural Sciences and Mathematics, University of Priština, Kosovska Mitrovica, Serbia
}

\begin{abstract}
In Serbia, there are se veral sites from the Neolithic period, but there is only one site from the period of existence of the Vinča-Tor doš family (5500-4800 BC). In this paper, we will try to become familiar with the site named Pločnik by using two methods. This site is one of many archeological sites in Serbia, but it stands out uniquely because it is under state protection. The methods to be applied are GAM model and tourist valorization.
\end{abstract}

Keywords: Archaeological site, GAM model, tourist valorization, Neolithic, Pločnik, Vinča-Tor doš.

\section{INTRODUCTION}

Neolithic period was divided into early and late neoliths. The older neolith involves the material remains of old-age culture from the 7 th to the mid 6th millennium BC. The beginning of early Neolithic brought many innovations. There was a settlement in one area, after which there was a transition from hunting and gatherings to agriculture and livestock breeding. New economic opportunities and sedentary lifestyles have spawned the emergence of new materials and new types of facilities. Clay, a new material suitable for its plasticity, has found wide application in the Neolithic period, but also in later periods. There are also tools of polished stones of different shapes, which are suitable for processing wood and leather and grinding grain. The late neolith ic and en eolithic contents contain objects belonging to the period from the middle of the 6th to the middle of the 5th millennium BC. The Vinca culture flourished during the late Neolithic and Eneolithic. Livestock and agriculture represent the economic base of this culture, and its bearers have begun and gradually completely mastered the use of copper. Stone foods and tools for animal bones appear, as well as the first metal artefacts - copper chisels, axis hammers, needles, beads, pendants and moldings, which testify to the beginning of old metal and the innovative spirit of Vinca culture. Early Neolithic sites on the territory of Serbia are Starcevo Near Pančevo, Pavlovac (Čukar and Gumnište) near Vranje, NosaPearl coast near Subotica, Tečić in Šumadija, Ajman, Mala Vrbica and Arija Babi in Đerdap, late neolithic sites Vinča-Belo Brdo in the Belgrade suburb, Pločnik near Prokuplje and Belovoda kod Petrovac na Mlavi.Na more important, the famous Neolithic site at the spa, causeway, was accidentally discovered in 1927, while he was digging for the route of the railway. Found objects, especially the storage of copper tools, which the Administration of the Ironworks gave to the Museum of Prince Pavle, were the reason why Dr. Miodrag Grbic made the first rescue excavation of this site the following year. On an area of

\footnotetext{
* Corresponding author: stefanmilovanovic2012@g mail.com GEOGRAPHY
}

about $500 \mathrm{~m} 2$, they found baked dishes, figurines, stone tools and bones, and another copper tools storage. This material was the basis for a publication published by the Belgrade Museum in 1929 in German, which made Pločnik one of the main European locations from the Eneolithic period.

Research in Pločnik was restored in 1960, organized by the National Museum in Belgrade.

The work was led by Dr. Blaženka Stalio, and systematic drilling research, with interruptions, lasted until 1978. In nine campaigns, $765.5 \mathrm{~m}^{2}$ were explored. The main purpose was to investigate and determine the boundaries of the village, whose stratigraphy is followed in the profile of the left coast of Toplica, where the 2-3.5 m thick cultural layer can be traced for almost kilometer in length, and where house foundations are clearly visible in the profile and pit profiles filled with a variety of amenities. The first probe was near the railway station and then probes followed the river profile, as this is the most vulnerable part of the village. Toplica in this part makes a meander, hits the high coast and undermines the gravel surface beneath the cultural layer. This way, only during the last 20 years, the river took almost 30 hectares of fertile land together with the site: http://muzejtoplice.org.rs/.

Research conducted in Pločnik gave plenty of material which characterized Pločnik as the Late Stone Age village, as well as the site from the period of Vinča culture, which in the region of the central Balkans lasted from 5500 to 4800 BC. In addition to the items which are usually found on the sites of this culture, foundations of houses, furnaces, fireplaces and pits, abundant ceramic material was discovered as well. A variety of vessels, from large and coarse to the polished ones, as well as various and extremely rich figural plastic with specific elements, have caused the late phase of the Vinča culture to be named after the site of Vinča-Pločnik.

Last survey campaign began in 1996 organized by the Belgrade National Museum and the Toplica National Museum from Prokuplje, under the leadership of MS. Dušan Šljivar from Prokuplje. Research gives excellent results and growing evidence of the beginning of copper metallurgy in this region: http://plocnik.org.rs/. 


\section{THEORETICAL PART}

The Pločnik site stretches on 120 hectare. On the West, it is bordered by Paljevski creek. On the East, there is a river Bačka. On the South, there is Toplica River and on the North there are traces of settlement up to the foot of the hills that enclose the valley. Recent research has given an extraordinary material: copper artifacts that move the beginnings of metallurgy to 500 years earlier, exquisite works of art that the world admires which awakened the interest in the scientific world for this site. In the immed iate vicinity of the site are: Roman baths, Church, Battle of Pločnik, spa Viča: http://www.prokuplje.org.rs/.

\section{EXPERIMENTAL}

\section{Materials and methods}

Methods for evaluating geosites that have been developed in previous years were mainly focused on geosites and their scientific value and later on, added value (Grandgirard, 1999; Bruschi \& Cendrero, 2005; Coratza \& Giusti, 2005; Reynard, 2005; Reynard \& Panizza, 2005; Reynard et al., 2007; Pereira et al., 2007; To mić, 2011; Vujičić et al., 2011; Boškov et al., 2015). Based on several of these methods, in 2005, Pralong (Pralong, 2005) has made a new model exclusively intended for the evaluation of geosite tourist value and the use of geosites in the tourism sector.

According to this method, the tourist value of the site is determined as the average value of aesthetic, scientific, cultural and economic values. In this model, as well as in many previous models, one of the main problems in the evaluation process is objectivity. None of these models include information on the needs, attitudes, interests and opinions of tourists visiting geosites which is of great importance especially in the evaluation of the tourist potential of the site. Including the visitors into the evaluation process is a good way to achieve greater objectivity.

Model for evaluation that was used in this study is based on the model for the evaluation of geosites (Geosite Assessment Model - hereinafter GAM), which was published in 2011 (Vujičić et al., 2011). During the creation of this model, extensive existing scientific literature in the field of the geosite evaluation was used (e.g. Hose, 1997; Hose et al., 2011; Bruschi \& Cendrero, 2005; Coratza \& Giusti, 2005; Pralong, 2005; Pereira et al., 2007; Serrano, González-Trueba, 2005; Zouros, 2007; Reynard et al., 2007; Reynard, 2008). GAM model is composed of two indicators: the main value $(M V)$ and the additional value $(\boldsymbol{A V})$, which are further divided into 12 or 15 subindicators (Table) which may have a value from 0.00 to 1.00 . Table 1.

Table 1. Structure model for evaluating geosites (GAM)

\begin{tabular}{|c|c|}
\hline Indicators/Subindicators & Description \\
\hline \multicolumn{2}{|l|}{ Main values $(M V)$} \\
\hline $\begin{array}{l}\text { Scientific/Educational value } \\
(V S E) \\
\text { Rarity }\left(S I M V_{1}\right) \\
\text { Representativeness }\left(S I M V_{2}\right) \\
\text { Site exploration }\left(S I M V_{3}\right) \\
\text { Interpretation level }\left(S I M V_{4}\right)\end{array}$ & $\begin{array}{l}\text { Number of identical sites in the immediate environment. } \\
\text { Didactic and "school" characteristics of the site based on its own qualities and general configuration. } \\
\text { Number of publications in recognized journals, master and doctoral theses and other publications. } \\
\text { Options for the interpretation of geological and geomorphological processes, forms and shapes. }\end{array}$ \\
\hline \multicolumn{2}{|l|}{$\begin{array}{l}\text { Landscape / aesthetic value } \\
\text { (VSA) }\end{array}$} \\
\hline Lookouts $\left(\operatorname{SIMV}_{5}\right)$ & $\begin{array}{l}\text { Number of lookouts available to pedestrian walkways. Each must provide a view from a different angle and } \\
\text { it must be located less than } 1 \mathrm{~km} \text { from the site. }\end{array}$ \\
\hline Surface area $\left(S I M V_{6}\right)$ & The total area of the site. Each locality is considered in the quantitative comparison with other localities. \\
\hline $\begin{array}{l}\text { Incorporation of localities in } \\
\text { the surroundings }\left(S I M V_{8}\right)\end{array}$ & The degree of contrast with nature, contrast, color, shape, etc. \\
\hline $\begin{array}{l}\text { Protection }(V P r) \\
\text { Current situation }\left(S I M V_{9}\right)\end{array}$ & The current state of geosite. \\
\hline Level of protection $\left(S I M V_{10}\right)$ & Locality protected by local or regional associations, national or international institutions. \\
\hline Sensitivity $\left(\operatorname{SIM} V_{11}\right)$ & Geosite Sensitivity Level / Vulnerability to natural or anthropogenic damage. \\
\hline Bearing capacity $\left(S I M V_{12}\right)$ & $\begin{array}{l}\text { Adequate number of visitors to the site at the same time which will not jeopardize the current state of } \\
\text { geosites. }\end{array}$ \\
\hline
\end{tabular}




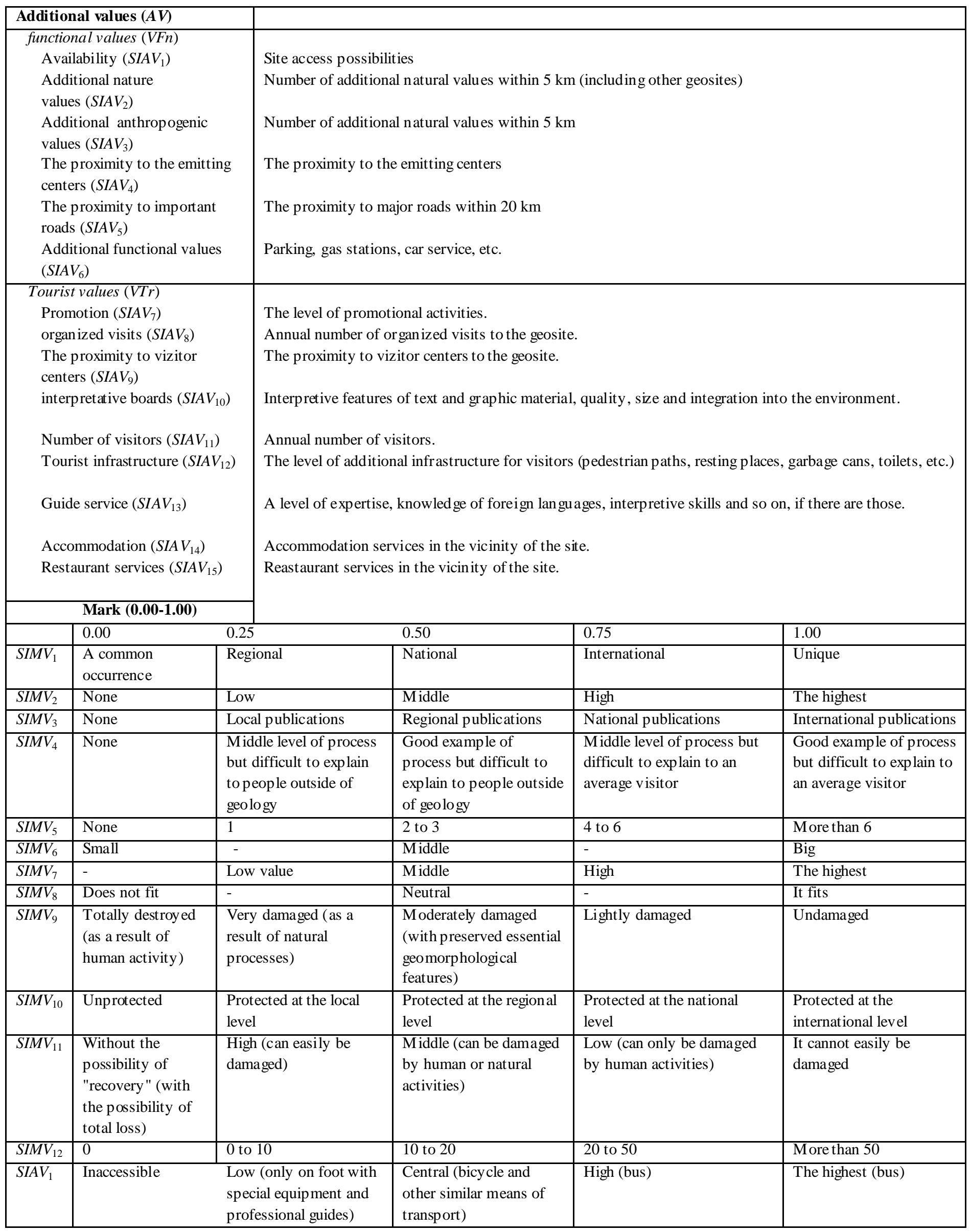




\begin{tabular}{|c|c|c|c|c|c|}
\hline $\operatorname{SIAV}_{2}$ & None & 1 & 2 to 3 & 4 to 6 & More than 6 \\
\hline $\operatorname{SIAV}_{3}$ & None & 1 & 2 to 3 & 4 to 6 & More than 6 \\
\hline $\operatorname{SIAV}_{5}$ & $\begin{array}{l}\text { There are not any } \\
\text { in the vicinity }\end{array}$ & Local road & Regional road & National road & International road \\
\hline $\operatorname{SIAV}_{6}$ & None & Low & Middle & High & The highest \\
\hline $\operatorname{SIAV}_{7}$ & None & Local & Regional & National & International \\
\hline$\overline{S I A V_{8}}$ & None & Less than 12 a year & From 12 to 24 a year & From 24 to 48 a year & More than 48 a y ear \\
\hline $\operatorname{SIAV}_{10}$ & None & Low quality & Average quality & High quality & The highest quality \\
\hline $\operatorname{SIAV}_{11}$ & None & Low (less than 5000) & $\begin{array}{l}\text { Middle (from } 5001 \text { to } 10 \\
000 \text { ) }\end{array}$ & $\begin{array}{l}\text { High (from } 10001 \text { to } 100 \\
000 \text { ) }\end{array}$ & $\begin{array}{l}\text { The highest (more than } \\
100000 \text { ) }\end{array}$ \\
\hline $\operatorname{SIAV}_{12}$ & None & Low level & Middle level & High level & The highest level \\
\hline $\operatorname{SIAV}_{13}$ & None & Low quality & Average quality & High quality & The highest quality \\
\hline
\end{tabular}

This division has been created by the two most typical kinds of values: main values - mainly stemming from the natural geosite characteristics; and the additional values - which are mostly caused human influence and the adjustments made for the visitors' needs. The main values (MV) consist of three groups of indicators: scientific/educational value (VSE), landscape/ aesthetic value $(V S A)$ and protection $(V p r)$. Additional values $(A V)$ are divided into two groups of indicators, functional (VFN) and the tourist value (VTR) (Vujič ić et al., 2011). So, we have a total of 12 sub-indicators of the main values and 15 subindicators of additional values which are assessed using values from 0.00 to 1.00 , which defines GAM as the following equation:

$$
G A M=M V+A V
$$

where $M V$ and $A V$ represent the symbols for main value and added value. As the main and additional values consist of three or two groups of sub-indicators, we can derive the following two equations:

$$
\begin{gathered}
M V=V S E+V S A+V P r \\
A V=V F n+V T r
\end{gathered}
$$

where, VSE, VSA, VPr, VFn and $V T r$ represent scientific/educational value (VSE), landscape/aesthetic value $(V S A)$, the protection $(V P r)$, the functional value $(V F N)$ and tourist value $(V T r)$.

Now that we know that each group of indicators consists of sub-indicators, the equations (2) and (3) can be written as follows:

$$
M V=V S E+V S A+V P r \equiv \sum_{i=1}^{12} S I M V_{i}
$$

where is: $0 \leq S I M V_{i} \leq 1$.

$$
A V=V F n+V T r \equiv \sum_{j=1}^{15} S I A V_{i}
$$

where is: $0 \leq S I A V_{j} \leq 1$.

Here, $S I M V_{i}$ and $S I A V_{j}$ represent 12 sub-indicators of the main values $(i=1, \ldots, 12)$ and 15 sub-indicators $(j=1, \ldots, 15)$ of additional values. In accordance with the orig inal definition of the GAM model (Vujičić et al., 2011), each of the sub-indicators can only be obtained from the following numerical values: 0.00 , $0.25,0.50,0.75$ and 1.00 .

Based on the results of the evaluation, we created a matrix of basic and additional values, where the values are represented by $X$ (main) and $Y$ (added value) axes. The matrix is divided into nine fields (zones), which are divided by the main lines of the network represented by $Z(i, j),(i, j=1,2,3)$. On the $X$ axis, main line networks have a value of four, while on the $Y$ axis they have five units. Compared to the hight of the mark, each estimated geosite belongs to a particular field.

The tourism potential of the given destination is determined by tourist valorization (evaluating the space and content), in terms of as sessment of the possibilities for the tourism economy. It implies a qualitative and quantitative assessment of fair value of a tourist motive. The motives that get the highest value can expect the largest tourist demand so the priority is given to them. It represents the process of evaluating the space and objects and the phenomena in them as an opportunity for the activation of touris m and economy.

Necessary gradualism and systematization of the implementation of the tourist valorization process shall be based on research from the general to the particular, from literature to field observations from past to future.

According to the formula of the World Tourism Organization (WTO) we will provide an inventory and ass essment of the tourism value of site Pločnik.

$$
\mathrm{X}=\mathrm{A}+\mathrm{B}+\mathrm{C}+\mathrm{D}
$$


where in $\mathrm{X}$ is a summation of estimates of internal factors, A assessment of urbanization, B - evaluation of infrastructure, C evaluation of equipment and services, and D - the estimation of inherent characteristics.

$$
\mathrm{Y}=\mathrm{E}+\mathrm{F}+\mathrm{G}+\mathrm{H}
$$

and $\mathrm{Y}$ is the sum of evaluation values of external factors of valorized values, E - accessibility assessment, F - assessment of the specificity of the resources, G- proximity to the emissive centers and $\mathrm{H}$ - value of resources assesment.

The research results are displayed numerically and they are ranked on a scale from 1 to 10 points.

\section{NUMERICAL RES ULTS}

For this study, it is important to objectively assess the site and its 27 indicators, when using GAM model, so that the site can have its social benefits. In the group of scientific and educational value VSE, the subindicator rarity is 0.50 , because in Serbia there are many sites from the Neolithic period, but this site is the only one from the Vinča-Tordoš period and in the vicinity there is only one in Macedonia.

Archaeological site Pločnik in our literature in the past is mentioned in the "color on the sidewalk" context, after 2009 the research began and it started getting the attention it deserves, that is why the representativeness is 0.25 . Publications on the site for the first time appeared in 1927, they were published in German, also scientific-research works concerning the site are on international websites, and in Europe it is gaining in importance as one of the first centers of metallurgy - exploration of the site 1.00. Most of the phenomena, processes and forms can be interpreted to visitors, from the impression one gets - the level of interpretation 0.75 .

All sub-indicators of landscape and aesthetic values VSA (lookouts, areas, landscapes and the surrounding nature, incorporation in the environment) are rated 0.50 on the ground that the site can clearly be seen from two angles, the area is 120 hectares, it is located in a relatively convenient location and surrounded by hospitable nature, and it partially merges with the environment. One of the important indicators of the site is the protection.

Subindicator current state receives a rating of 0.25 for the reason that a big problem is the ground on which the site is located because it is subject to erosion. The level of protection 0.75 at the state level and the site Pločnik is a monument of the neolithic culture (Gavrilović et al., 1998). The level of site sensitivity and erosion threatens the human factor and therefore the mark is 0.25 . The number of visitors who remain in the vicinity of the site, meets a certain level of standard, the mark is 0.75 .

From all the above mentioned information, we conclude that the main value of the site, in our opin ion, after considering all the parameters, the site deserves 6.50 out of 12 .
In the group of functional values VFn, subindicator accessibility deserves the highest mark of 1.00, the site can be reached by bus and train, the proximity to the highway and the railroad is $20 \mathrm{~m}$. Within $5 \mathrm{~km}$ reach there are no other additional natural values of 0.00 . In the vicinity of Pločnik there are sites of Roman thermal spa and the city of Milan Toplica (Vasić \& Marinković, 1999) as additional anthropogenic value of 0.50 . Important emissive centers nearby are Krušumlija, Prokuplje, Podujevo, Blace, therefore the subindicator deserves 0.75 .

Table 2. Main and additional values of the geosite Pločnik MV

\begin{tabular}{|c|c|}
\hline Indicators & $\begin{array}{c}\text { Mark } \\
(0,00-1,00)\end{array}$ \\
\hline Scientific/educational value VSE & 2,50 \\
\hline Rarity SIMV1 & 0,50 \\
\hline Representativity SIMV2 & 0,25 \\
\hline Exploration of the site SIM V3 & 1,00 \\
\hline The level of interpretation SIMV4 & 0,75 \\
\hline Landscape/aesthetic value VSA & 2,00 \\
\hline Lookouts SIMV5 & 0,50 \\
\hline Surface area SIM V6 & 0,50 \\
\hline Landscape and nature around it SIM V7 & 0,50 \\
\hline $\begin{array}{l}\text { Incorporation of the locality in the } \\
\text { surroundings SIM V8 }\end{array}$ & 0,50 \\
\hline Protection VPr & 2,00 \\
\hline Current state SIMV9 & 0,25 \\
\hline The level of protection SIM V10 & 0,75 \\
\hline Sensitivity SIM V11 & 0,25 \\
\hline Bearing capacity SIMV12 & 0,75 \\
\hline VSE+VSA+VPr & $\mathbf{6 , 5 0}$ \\
\hline Additional values AV & \\
\hline Functional values VFn & 3,00 \\
\hline Accessibility SIAV1 & 1,00 \\
\hline Additional natural values SIAV2 & 0,00 \\
\hline Additional anthropogenic values SIA V3 & 0,50 \\
\hline The proximity to the emitting centers SIAV4 & 0,75 \\
\hline The proximity to the main roads SIAV5 & 0,75 \\
\hline Additional functional values SIA V6 & 0,00 \\
\hline Touristic values VTr & $\mathbf{2 , 5 0}$ \\
\hline Promotion SIAV7 & 0,50 \\
\hline Organised visits SIAV8 & 0,25 \\
\hline The proximity to the visitor centres SIV9 & 0,25 \\
\hline Interpretation boards SIAV10 & 0,50 \\
\hline The number of visitors SIAV11 & 0,25 \\
\hline Tourist infrastructure SIAV12 & 0,00 \\
\hline Guide service SIAV13 & 0,50 \\
\hline The accommodation services SIAV14 & 0,50 \\
\hline Restaurant services SIAV15 & 0,25 \\
\hline VFn+VTr & $\mathbf{5 , 5 0}$ \\
\hline
\end{tabular}

Archaeological site Pločnik is located close to major roads, the highway E-80 Niš-Priština Fig. 2, roadway IIB No. 38 connects Blace-Beloljin as well as the roadway IIA number 213 which connects Kuršumlija-Blaževo, also in the immediate vicinity there is a railway line Niš-Kuršumlija, thus the 
subindicator got 0.75 . Additional functional values of 0.00 are in Kuršumlija Table 2.

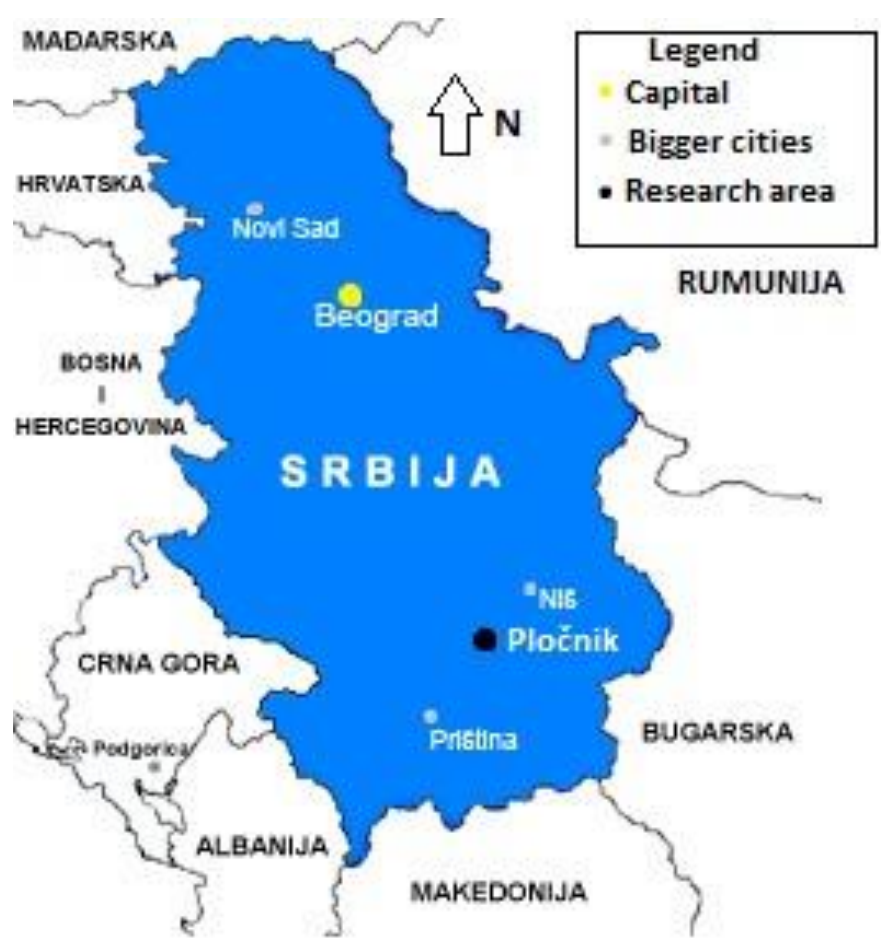

Figure 1. Geographical location of Pločnik

Tourist values VTr, subindictor of site promotion 0.50 , deserved its mark due to occasional conferences. Organized visits to the site appear in the form of school excursions and certain individuals, mark 0.25 . In the vicinity of the site there is a visitor center Devil's Town at a distance of about $30 \mathrm{~km}$ and the mark is therefore 0.25 . Interpretative tables deserve 0.50 ; there is a medium quality panel on the main road E-80, visible to visitors. Number of visitors deserves 0.25 ; it is not satisfactory because other than organized visits the individual visits are rare. Tourist infrastructure is 0.00 , it is almost nonexistent. Travel Service, 0.50 , the site meets the needs of visitors to a certain level. In the immediate vicinity of the site, there are only private accommodations and no other accommodation facilities, the closest are in Kursumlija, mark 0.50. Closest restaurant services, 0.25 , can be obtained in nearby towns.

Table 3: Results of the GAM model

\begin{tabular}{|c|c|c|c|c|}
\hline \multicolumn{5}{|c|}{ Results } \\
\hline \multicolumn{5}{|c|}{ Main } \\
\hline VSE+VS A+VPr & $\sum$ & VFn+VTr & $\sum$ & Field \\
$2,50+2,00+2,00$ & 6,50 & $3,00+2,50$ & 5,50 & $\mathrm{Z}_{22}$ \\
\hline
\end{tabular}

The results of the archaeological site are shown in box $Z_{22}$ in GAM chart. This means that the position from the obtained results represents an intermediate level Fig. 2. On the basis of mathematical and statistical analysis, the archaeological site Pločnik has a favorable "climate" for a tourist attraction .

From all of the above, we conclude that the added value of the site in our opinion, after considering all the parameters, of a possible 15 points, the site deserves 5.50 Table 3 .

After a detailed analysis of the main and additional site values, following the pattern of M-GAM model, out of possible 27 points, the locality Pločnik achieved 12.00 points.

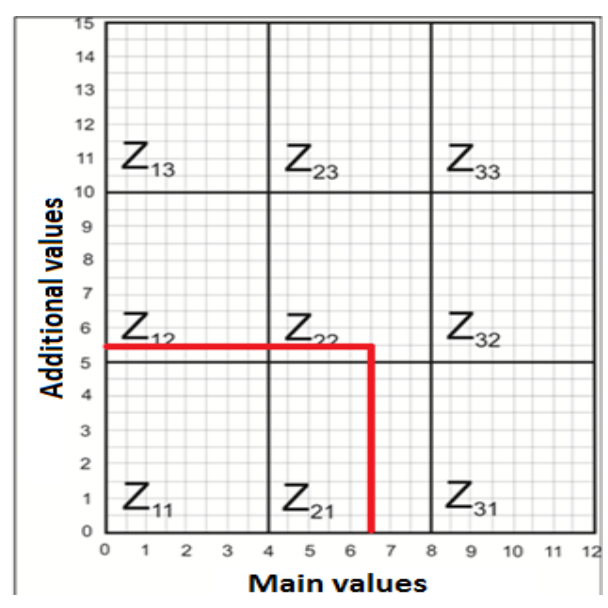

Figure 2. Graph ic results of the site Pločnik GAM model

From all the above, we conclude that the site has the potential to become one of the visitor centers of the district where it is located, but in order to achieve this it must be valorized much better. That's why in the second part of our work we will try to make a sense of what should be done in order for the site to be recognized at national and even international level.

The universal formula for the calculation of tourist valorization (Stanković, 2008):

$\mathrm{X}=\mathrm{A}+\mathrm{B}+\mathrm{C}+\mathrm{D}$ (the sum of the assessment of internal factors )

$\mathrm{Y}=\mathrm{E}+\mathrm{F}+\mathrm{G}+\mathrm{H}$ (the sum of the assessment of external factors )

A - the ass essment of the urbanization;

$\mathrm{B}$ - the as sessment of infrastructure;

$\mathrm{C}$ - the as sess ment of equip ment and services;

D - the assessment of inherent characteristics;

$\mathrm{E}$ - the ass ess ment of accessibility;

$\mathrm{F}$ - the assessment of specificity of resources;

$\mathrm{G}$ - the as sessment of the proximity to emis sive centers;

$\mathrm{H}$ - the ass sessment of the importance of resources.

Site factors got relatively high marks because their condition is perfect but the problem is that they are not adequately valorized, we see in the Table 4 . 
Table 4. Internal and external factors of the site called Pločnik

\begin{tabular}{|c|c|c|c|c|c|c|c|c|c|c|c|c|c|}
\hline & Factors & \multicolumn{3}{|c|}{ Mark } & \multicolumn{3}{l|}{ Total } \\
\hline $\mathrm{X}$ & Internal factors & 1 & 2 & 3 & 4 & 5 & 6 & 7 & 8 & 9 & 10 & \\
\hline A & Urbanization assessment & & $*$ & & & & & & & & & \\
\hline B & Infrastructure assessment & & & & & & & $*$ & & & \\
\hline C & Equipment and services assessment & & & & & $*$ & & & & & & \\
\hline D & Inherent characteristics assessment & & & & & & & & $*$ & & & \\
\hline & Total (X=A+B+C+D) & & & & & & & & & & & 23 \\
\hline Y & External factors & & & & & & & & & & & \\
\hline E & Accessability assessment & & & & & & & & & $*$ & & \\
\hline F & The specificity of resources evaluation & & & & & & & & & & $*$ & \\
\hline G & Assessment of proximity to the emitting centers & & & & & $*$ & & & & & & \\
\hline H & Assessment of importance of resources & & & & & & & & & & $*$ & \\
\hline & Total (Y=E+F+G+H) & & & & & & & & & & & 34 \\
\hline
\end{tabular}

\section{CONCLUSION}

By applying GAM model to the geosite called Pločnik and by its detailed elaboration, we recognize that the geosite is not on a satisfactory level taking into consideration the parameters set by the model. One of the key parameters that model prescribes is the appearance and rarity of the site, which by the model criterion got top marks, but the major drawback is that these two parameters are not sufficiently interpreted to the public. Another parameter which is not less important than the previous two, is the "consciousness", ie. disinterest of local population for the site, which is essential for its preservation.

On several occasions, it was attempted by means of tourist valorization to perceive all the shortcomings of the site, but each attempt was insufficiently developed. This locality, as an independent tourist value, could attract a number of tourists, but from certain groups because it represents a prehistoric way of being. Should there be unification of Toplica and Jablanica districts in terms of tourism potential, this site would be one of the major destinations on the tourist map of the district, and Serbia as well.

In an attempt to get to know the site called Pločnik, we applied two methods: GAM model and tourist valorization. We came to the conclusion that the site has resources, but it also has small shortcomings. In the vicinity of the site there is an important highway Niš-Priština, and there is also a plan for a highway leading to the Adriatic Sea to be built. Thus, with some effort, the site could become a waystation for all the users of this road.

Should there be a unification of the tourist offer of the district of Toplica, Jablanica, Ibar-Kopaonik as it did in Western Serbia, a tourist offer could be created and it would bring together all the potential of this part of Serbia including the site Pločnik.

In our opinion, for the tourists who travel from Bulgaria to Kopaonik, a touris m offer might look like this: Niš, Prokuplje, PLOČNIK, Prolom Spa, Devil's town, Prolom Spa, Kuršumlija's Spa, Kopaonik (the source of Toplice River) Jošanička banja, Župa's vineyards, Ćelije Lake and the church Lazarica in Kruševac. This way, we would get a round of complementarycomplex tourist values.

\section{REFERENCES}

Bruschi, V.M., \& Cendrero, A. 2005. Geosite evolution. Can we measure intantgible values?. II Quaternario, 18(1), pp. 293 316.

Coratza, P., \& Giusti, C. 2005. Methodological proposal for the assessment of the scientific quality of geomorphosites. II Quaternario, 18(1), pp. 307-313.

Gavrilović, D., Menković, L.J., \& Belij, S. 1998. Zaštita geomorfoloških objekata u geonasleđu Srbije.Beograd: Zavod za zaštitu prirode Srbije. 
Hose, T.A. 1997. Geotouris m-selling the earth to Europe. In P.D. Marinos, G.C. Koukis, G.C. Tsiambaos, \& G.C. Stournaras Eds., Engineering geology and the environment.Rotterdam: A. A Balkema., pp. 2955-2960.

Hose, T.A., Marković, S.B., Komac, B., \& Zorn, M. 2011. Geotourism: A short itroduction. Acta Geographica Slovenica, 51(3), pp. 339-342.

Pereira, P., Pereira, D., \& Alves, C. 2007. Geomorphosite assessment in Montesinho Natural Park (Portugal). Geographica Helvetica, 62, pp. 150-168.

Pralong, J.P. 2005. A method for assessing the tourist potential and use of geomorphological sites. Géomorphologie. Relief, Processes, Environnement, 3, pp. 189-196.

Reynard, E. 2008. Scientific research and tourist promotion of geomorphological heritage. Geografia fisica e dinamica quaternaria, 31(2), pp. 225-230.

Reynard, E., Fontana, G., Kozlik, L., \& Scapozza, C. 2007. A method for assessing "scientific" and "additional values" of geomorphosites. Geographica Helvetica, 62(3), pp. 148-158.
Serrano, E., \& González-Trueba, J.J. 2005. Assessment of geomorphosites in natural protected areas: The Picos de Europa National Park (Spain). Géomorphologie, Formes, Processus, Environnement, 3, pp. 197-208.

Stanković, S. 2008. Turistička geografija.Beograd: Zavod za udžbenike.

Vasić, M., \& Marinković, D. 1999. Prokuplje u Praistoriji, Antici i Srednjem veku. Beograd: Arheološki Institut.

Vujičić, M.D., Vasiljević, D.A., Marković, S.B., Hose, T.A., Lukić, T., Hadžić, O., \& Janićević, S. 2011. Preliminary geosite assessment model (GAM) and its application on Fruška Gora Mountain, potential geotourism destination of Serbia. Acta Geographica Slovenica, 51(2), pp. 361-377.

Zouros, N.C. 2007. Geomorphosite assessment and management in protected areas of Greece. The case of the Lesvos island coastal geomorphosites. Geographica Helvetica, 62, pp. 169180.

Retrieved from http://muzejtoplice.org.rs/

Retrieved from http://plocnik.org.rs/

Retrieved from http://www.prokuplje.org.rs/ 